\title{
Learner Corpora in an EFL Context: An Analysis of College Low-Achievers' Conjunction Applications
}

\author{
By Pei-Ling Yang*
}

\begin{abstract}
Cohesion plays a significant role in language learning; however, little attention has been paid to it in English education in Taiwan. English writing, for the majority of learners in Taiwan, indeed makes them nervous and anxious, especially for low-achievers, and then gradually, they write less and less. This current study therefore aims to investigate narrative compositions written by EFL college low-achievers. A corpus of 192 compositions was collected from two classes of college freshmen who were randomly selected out of 23 classes in one technological university. The participants were asked to fill out the background information questionnaire and English selfefficacy scale before they worked on writing compositions. In the second semester of 2014, they were required to write three pieces of narrative compositions with the words provided by the instructor. Not only quantitative analysis would indicate the cohesive conjunctions applied by the EFL college low-achievers, but also cohesive problems would be revealed through qualitative analysis. The findings showed that the participants only applied a limited range of conjunctions in their writing, and they were unaware of the significance of cohesion.
\end{abstract}

Keywords: Cohesion, Conjunctions, EFL learners, Narratives

\section{Introduction}

English has long been deemed the most significant foreign language in Taiwan. However, learning English in an EFL context is not an easy task. To master English language, learners need to have sufficient language input and output. English writing, among the four language skills, is always the least favored subject for Taiwanese learners. In Taiwan's English education, the Grammar Translation Method (GTM) or test-oriented instruction, as opposed to communicative approaches, has long been over-emphasized (Bax 2003). The language learners, under this learning context, would easily become much more passive, waiting for correct answers from the authoritative figures. Teachers are traditionally deemed as authority figures, dominating the whole classroom instruction, especially in a Chinese society. Gradually and unfortunately, memorization and rote-learning have almost occupied the ideas of language learning in Taiwan learners' minds (Wei 2004). A few years ago, Taiwan's government launched a new and a less GTM-oriented education policy (a twelveyear basic education program), shifting the learning focus to learners' communicative ability. Through this emphasis, it would be easier for learners in Taiwan to get more connected to the world outside the restricted and designated classroom contexts. Nowadays, when the government in Taiwan begins doing something different to bridge the gap between language knowledge and language communicative competence, the language teachers should be more like consultants, advisers, helpers, coordinators, and idea people (Oxford 1990). Their instructional aims should not be on producing perfect test takers, but rather on creating an environment in which language learners are offered opportunities to

\footnotetext{
* Associate Professor, Center for General Education, Oriental Institute of Technology, Taiwan.
} 
practice the target language for different purposes or needs. Thus, to encourage students to use the target language for communication should be the priority in Taiwan's English education.

Since the focus of language education has been shifted from a more teacherdominated to a more interactive and communicative one (Tarone and Yule 1989), English teachers and curriculum designers should be more aware of the significance of language in use as a coherent and cohesive whole, not a separate and awkward segment. The importance of coherence or cohesion is seldom shown or taught in Taiwan's formal English education. However, coherence or cohesion plays an influencing part in producing a more interactive or communicative oral and written discourse. Particularly in a written discourse, it would not be more convenient for readers to comprehend or understand writers if the writers do not apply coherent or cohesive elements to their writing.

Cohesion is one of the weighty measures to examine writers' competence. Cohesion, divided into grammatical and semantic cohesion, plays a significant role to define a well-organized text in addition to coherence (Halliday and Hasan 1976, Divsar and Heydari 2017). Different from coherence, cohesion could be observed and analyzed. Halliday and Hasan (1976: 31-33) claim that the grammatical and semantic parts become cohesive only within the situation in which they are interpreted through relations with the other parts in a text. Only a singular part could form a cohesive text. Grammatical cohesion includes reference, substitution, ellipsis, and conjunction, while semantic cohesion includes reiteration and collocation (Halliday and Hasan 1976). In other words, cohesion is to make a discourse text an integrated and logical one. Therefore, cohesion, an effective method for language production and interpretation (Tanskanen 2006), should be highlighted in English education, particularly in an English as a Foreign Language (EFL) context. In an EFL environment, language learners do not receive sufficient input and often lack enough chances for language output. Drills and practice are over-emphasized in EFL curriculum; on the contrary, discourse cohesion is often neglected or ignored. Gradually, learners within this learning context tend to focus too much on language segments, rather than on a united whole utiliizing linguistic techniques to smoothly and logically combine single sentences or clauses together.

Five principal classes of cohesive ties, categorized by Halliday and Hasan (1976), are to offer objective criteria for analyzing language learners' linguistic production. The ties include reference, substitution, ellipsis, conjunction, and lexical. Among the five classes, conjunctions are selected as an assessing tool in the study for its practical function to combine words, phrases, or clauses together. Conjunctions, including an adverb, prepositional phrase or linking adverbial, are cohesive elements to express a semantic relation by its particular meanings (Halliday and Hasan 1976). The mother tongue of the study participants, Chinese, is claimed to be coherent with fewer conjunctions, while the target language, English, requires conjunctions to form a well-united discourse. Different scholars classify conjunctions in a slightly different way; in the current study, the version of Halliday and Hasan (1976) was applied: conjunctions and linking adverbials as one category. Thus, the category of conjunctions examined in the study is presented in Table 1. 
Table 1. Category of Conjunctions

\begin{tabular}{|l|l|}
\hline Category & Examples \\
\hline Additive & and, or, both...and..., in addition \\
\hline Adversative & but, although, however \\
\hline Causative & so, therefore, because \\
\hline Temporal & then, next, after that \\
\hline
\end{tabular}

Narrative, one of the fundamental written forms, serves as an influencing index to examine writers' linguistic competence and pragmatic application in a target language (McClure 1993). Different from oral discourse, written narrative is a writing process requiring deliberation and edition (Chafe 1985), allowing language learners to present their best performance. Through analyses of written narrative, language learners' linguistic strengths and weakness can be unfolded. The clarity of their performance might light up a way to bridging the gap between native speakers and language learners.

Writing quality is significantly correlated with the skillful application of cohesive devices, supported by the studies aiming at young-aged native English writers (Cameron et al. 1995, Cox et al. 1990). Relevant studies show that English composition between native- and non-native English writers differ in the numbers and types of cohesive ties (Reid 1992). Previous studies conducted in Taiwan mainly focus on secondary or graduate school students (Hung 2003, Lo 2003, Chen 2006). However, little research has been targeted at college students in terms of conjunction application, especially those with lower levels of English proficiency and English learning self-efficacy.

Thus, the current study aims to examine EFL college low-achievers' cohesion application in order to promote their English writing performance. The study was conducted with the following two research questions and its analysis framework was in accordance with Halliday and Hasan's Cohesion in English (1976).

\section{Research Questions}

1. What are the cohesive features in the narrative writing applied by EFL college low-achievers?

2. What are the problems regarding the use of cohesion produced by EFL college low-achievers?

\section{Method}

\section{Participants}

The participants in this present study consisted of two classes of EFL learners, randomly selected out of 23 classes in a technological university in northern Taiwan. Both classes of participants were freshmen attending a compulsory freshman-level English course for one academic year. In the academic year, they were taking a two-hour English class per week. They were all native speakers of Mandarin Chinese and on average, they had received 10.77 years of formal EFL education (Table 2). Their average CSEPT scores on a paper-and-pencil were 
134.48, equal to the level of $\mathrm{A} 2$ on the scale of The Common European Framework of Reference for Languages: Learning, Teaching, Assessment (CEFR). Compared with average college EFL learners (the level of B1), the English proficiency of the participants was much lower. Before the study, they were all required to answer the English self-efficacy questionnaire (Likert scale, ranging from 1 to 5), adapted from Huang and Chang's ESL General Self-Efficacy Questionnaire (1996). The results showed that their level of English self-efficacy was not high $($ Mean $=2.96)$.

Table 2. Participants' Background Information

\begin{tabular}{|l|c|c|c|c|c|}
\hline Class & $\begin{array}{c}\text { No. of } \\
\text { Participants }\end{array}$ & Age & $\begin{array}{c}\text { Years of English } \\
\text { Learning }\end{array}$ & $\begin{array}{c}\text { CSEPT } \\
\text { Scores }\end{array}$ & $\begin{array}{c}\text { English Self- } \\
\text { Efficacy }\end{array}$ \\
\hline 1 & 32 & 19.38 & 10.50 & 136.30 & 2.95 \\
\hline 2 & 32 & 19.25 & 11.03 & 132.66 & 2.97 \\
\hline
\end{tabular}

\section{Procedures}

During the second semester of 2014, all the participants were required to compose three pieces of narrative essays in English. The essays were written during the class hour and sent to Moodle, a teaching and learning platform available to all faculty members and students in the target university. Before their writing, the participants were asked to fill out their background information and English self-efficacy scale (Figure 1). For each piece of writing, they were asked to use certain types of grammatical tense and apply some keywords to their writing. Because of their low level of English proficiency, they only needed to write at least eighty English words and were offered 30 to 40 minutes to finish each essay. The first essay was conducted on the third week; the second, on the eighth week; the third, on the fifteenth week. After finishing writing, they were not taught the mistakes or errors they had made. A good collection of the EFL lowachievers' writing was the main goal of the study procedure. The topics for the three essays were highly related to the participants' daily life or real experiences. Table 3 is the summary for essay topics and requirements.

Figure 1. Procedures of the Study

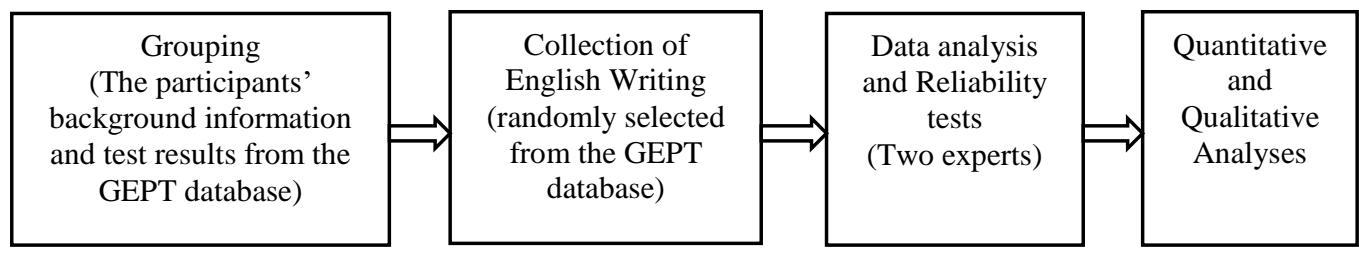

Table 3. Essay Topics and Requirements

\begin{tabular}{|c|c|c|c|}
\hline Essay & Topic & $\begin{array}{c}\text { Grammatical } \\
\text { Tense }\end{array}$ & Keywords \\
\hline 1 & An unforgettable experience & Past Tense & unforgettable, experience \\
\hline 2 & $\begin{array}{c}\text { A summer vacation during my } \\
\text { high school years }\end{array}$ & Past Tense & $\begin{array}{c}\text { summer vacation, high } \\
\text { school }\end{array}$ \\
\hline 3 & My future & Future Tense & Thirty years old, I will... \\
\hline
\end{tabular}




\section{Transcription and Categorization}

Each piece of writing, based on Halliday and Hasan (1976), was collected and then analyzed and categorized into the following five major conjunction classes: Additive, Adversative, Causative, and Temporal. Two experts in the English as a Foreign Language (EFL) field were recruited to evaluate the collected writing according to the conjunction category table. Wordsmith Software (version 6.0) was also applied in the study to analyze the most frequent conjunctions in this learner corpus. The results from the two experts were tested for reliability. Cohen's kappa was 0.82 for the participants' cohesive conjunctions.

\section{Results}

\section{Cohesive Features}

The most frequently applied cohesive conjunctions for both groups were "but" in the adversative category, followed by "and" in the additive category, and "because" in the causal category (Table 4). Among the four categories, adversative conjunctions were most frequently used by the participants (155 out of 455 times) while the least frequently used were temporal conjunctions (48 out of 455 times). Their average word count ranged from 56 to 138, and the frequency of using conjunctions was $2 \%$ in maximum.

Table 4. Frequency of Conjunction Application by the Participants

\begin{tabular}{|l|c|c|c|}
\hline Category & Total & Conjunctions & Frequency \\
\hline Additive & 79 times & and & $91.14 \%$ \\
\hline & & and also & $2.53 \%$ \\
\hline & & or & $2.53 \%$ \\
\hline & & that is & $2.53 \%$ \\
\hline & & besides & $1.26 \%$ \\
\hline Adversative & 155 times & but & $86.45 \%$ \\
\hline & & though & $12.26 \%$ \\
\hline & & however & $0.65 \%$ \\
\hline Casual & 125 times & in fact & $0.65 \%$ \\
\hline & & because & $56 \%$ \\
\hline & & so & $43.2 \%$ \\
\hline Temporal & 48 times & therefore & $0.8 \%$ \\
\hline & & then & $58.33 \%$ \\
\hline & & before that & $10.42 \%$ \\
\hline & & finally & $10.42 \%$ \\
\hline & & at that time & $10.42 \%$ \\
\hline
\end{tabular}

Below are examples directly quoted from their compositions.

Additive Category

S1: One time I past my senior high school, many memories show up in my heart, and I know I love them very much. 
Adversative Category

S2: On one day, I bought a umbrella in the shop. But on the same day I lost it on the bus.

\section{Casual Category}

S3: Because it was went to Vietnam, there was also a Vietnamese stewardess on the plane.

\section{Temporal Category}

S4: Then I got up, I found I was over sleep. This is an unforgettable experience.

Table 5 presents the findings of similar research, showing that the majority of EFL learners seem to have a certain level of conjunction difficulty. The sources of difficulty could be categorized into three aspects: insufficient knowledge of English conjunctions, limited chances for practice and correction, and L1 transfer. In accordance with the previous studies, the present research reveals the restricted number of conjunction types applied by the EFL learners. However in contrast to previous studies, this study unfolds the participants' unawareness of the conjunction application through the conjunction survey.

Table 5. Relevant Conjunction Studies

\begin{tabular}{|c|c|c|}
\hline Research & Participants & Findings \\
\hline $\begin{array}{l}\text { Bolton et al. } \\
(2003)\end{array}$ & $\begin{array}{l}\text { College students from } \\
\text { Hong Kong }\end{array}$ & $\begin{array}{l}\text { 1. A limited range of conjunctions } \\
\text { 2. Overuse "so", "and", and "but" }\end{array}$ \\
\hline Hung (2003) & $\begin{array}{c}\text { Senior high school } \\
\text { students from Taiwan }\end{array}$ & $\begin{array}{l}\text { 1. Misuse complicated English } \\
\text { conjunctions } \\
\text { 2. Negative transfer from L1 }\end{array}$ \\
\hline Lo (2003) & $\begin{array}{l}\text { Senior high school } \\
\text { students from Taiwan }\end{array}$ & $\begin{array}{ll}\text { 1. } & \text { Misuse connectors } \\
\text { 2. Insufficient knowledge about } \\
\text { conjunctions }\end{array}$ \\
\hline Chen (2006) & $\begin{array}{l}\text { Graduate students } \\
\text { from Taiwan }\end{array}$ & $\begin{array}{l}\text { 1. A limited range of conjunctions } \\
\text { 2. The most-frequently-used = Additive } \\
\text { conjunctions }\end{array}$ \\
\hline $\begin{array}{l}\text { Xu and Liu } \\
(2012)\end{array}$ & $\begin{array}{c}\text { Senior high school and } \\
\text { college students from } \\
\text { China }\end{array}$ & $\begin{array}{l}\text { 1. A limited range of conjunctions } \\
\text { 2. Overuse "but", "however", and } \\
\text { "though" }\end{array}$ \\
\hline Hamed (2014) & $\begin{array}{c}\text { College students from } \\
\text { Libya }\end{array}$ & $\begin{array}{l}\text { 1. Negative transfer from L1 } \\
\text { 2. Overgeneralization of English rules } \\
\text { 3. Unclarity in course books }\end{array}$ \\
\hline
\end{tabular}

\section{Cohesive Problems}

Besides the above findings about conjunction application and the comparison with other relevant studies, the study also revealed several cohesive problems produced by the EFL college low-achievers. The problems included misuse, overuse, and zero use. First of all, the participants seemed to have insufficient knowledge of conjunctions and their appropriate usage. Example 1 showed that the participants did not fully understand that the word "then" could not be applied 
to combine two complete sentences. In addition to this, in some situations, the participants' misuse would probably be influenced by their native language. In Chinese, "although and but" and "because and so" can be shown in one complete clause. Below are the examples of Chinese sentences and the direct translation to English.

因為天氣很好, 所以我要去健行。

Yin1Wei4Tian1Qi4Hen3Hao3, Suo3Yi3Wo3Yao4Qu4Jian4Xing1.

Because the weather is fine, so I will go hiking.

雖然他生病了, 但是他還是去上學。

Sui1Ran2Ta1Shen1Bing4Le0, Dan4She4Ta1Tai2Shi4Qu4Shang4Xue2.

Although he was sick, but he still went to school.

\section{Example 1}

I was enjoy in that, suddenly, I was out of balance then I fall.

\section{Example 2}

Although this trip was tired, but my unforgettable experience was look at the scenery in Pingtung.

\section{Example 3}

Because when elementary school, I learned German, always wanted to go to Germany, so I old enough my parents agreed to let me go.

The participants also overuse certain conjunctions. The conjunction appeared too many times in this kind of short writing. Example 4 and 5 presented that "but" almost appeared in every other sentence.

\section{Example 4}

I will have a good salary job. But work over time every day. I feel tired like a dog complained boss sometime. But I think I love my job. In spite of earn not much money to buy house. Maybe have an object still could not get married. Facing the future have many Unknown number but my life is happiness.

\section{Example 5}

In high school, our summer vacation in the summer school tutoring, because we were about to face the university exam. 8:00 every day, went to school, sometimes already 3:00 class, but the teacher will asked us to continue staying in school or exams, but almost all of the exam. But because of this long time to get along down, everyone in our class all get along very well

In addition to the above mentioned, some participants applied no conjunctions at all. Example 6 served a good example of zero conjunction. The writing was made up of separate units.

\section{Example 6}

When I am thirty years old, I am a mechanical engineer famous, I will take a pretty wife, make a cute children, buy a biggest car, take care of monkey dog, 
Open the big company, have a thousands of staff, annual turnover over One hundred million,

\section{Example 7}

Many schools looking for me to give a speech, I have to teach students to choose the department in accordance with their own interests, do not follow their own moment of confused random selection Chancellor of appreciation presented to me, says Dr. Wang Weigum, ha ha this is very cool, you can tell me I am very good man, I will very happy.

\section{Conjunction Survey}

The findings of the survey show that all the participants (100\%) have heard of English conjunctions before and $98.4 \%$ of them have been taught conjunctions at senior high school. Three sentences were selected from the learners' writing corpus and edited for some grammatical parts. However, when asked to identify the correctness of each sentence, they fail to do so. Table 6 shows that they do not possess sufficient knowledge of English conjunctions and cannot distinguish the correct sentence from the incorrect one. $29.7 \%$ of the participants thought the sentence was correct, while $65.6 \%$ considered it incorrect, but they could not show the reasons. Some even answered "then" should be replaced by "than". 48.4\% thought Sentence 2 was correct, and $40.6 \%$ took Sentence 3 as an incorrect one, but could not provide the reasons either. Overall, less than $36 \%$ of the participants could tell the correct conjunction applications from the incorrect ones.

Table 6. Findings of the Conjunction Survey

\begin{tabular}{|c|c|c|c|c|c|c|c|c|}
\hline Sentence 1 & Frequency & \% & Sentence 2 & Frequency & \% & Sentence 3 & Frequency & \% \\
\hline A & 19 & 29.7 & A & 31 & 48.4 & A & 15 & 23.4 \\
\hline B & 42 & 65.6 & B & 13 & 20.3 & B & 26 & 40.6 \\
\hline C & 3 & 4.7 & C & 20 & 31.3 & C & 23 & 35.9 \\
\hline Total & $\mathbf{6 4}$ & $\mathbf{1 0 0 . 0}$ & Total & $\mathbf{6 4}$ & $\mathbf{1 0 0 . 0}$ & Total & $\mathbf{6 4}$ & $\mathbf{1 0 0 . 0}$ \\
\hline
\end{tabular}

Note: Sentence 1 = I enjoyed that; suddenly, I was out of balance then I fell.; Sentence $2=$ Although this trip was tiring, but my unforgettable experience was to look at the scenery in Taiwan.; Sentence 3 = Because I learned Japanese, so I always wanted to go to Japan.; A = The participants thought the sentence was correct.; $\mathrm{B}=$ The participants thought the sentence was incorrect but they could not explain the reasons.; $\mathrm{C}=$ The participants thought the sentence was incorrect and they could explain the reasons.

\section{Discussions}

The analysis of narrative writing showed a similar pattern to that of several studies. The EFL college low-achievers applied a limited number of conjunctions and tended to overuse certain types of conjunctions. They highly preferred "but," "and," and "because." Among the four conjunction categories, the participants significantly relied on adversative conjunctions, while the temporal conjunctions were applied least to their writing. The required essays were narratives describing their past experiences and imagining their future lives. They could make their writing more diverse and attractive by applying 
different sorts of conjunctions, but on the contrary they only used one or two kinds of conjunctions (Xu and Liu 2012) or merely repeated one or two conjunctions through the whole writing. The study findings are in accordance with previous research (Hung 2003, Lo 2003, Chen 2006).

It could also be suggested that the negative transfer of L1 could have an influencing effect on L2 learning (Hung 2003, Sumonsriworakun and Pongpairoj 2017). A negative transfer could be diverted to a positive one through more focus on comparison of the two languages or through more chances for practice. In addition to the above mentioned, contents of the EFL materials also need adjusting (Hamed 2014) in order to incorporate conjunction knowledge and its application in a more organized and systematic way.

\section{Conclusions}

EFL college low-achievers only apply a limited range of conjunctions. "But", "and", and "because" are overused and mis-used by the college learners. EFL course materials seem to lack enough conjunction knowledge and applications. The gap between an EFL context and a real-life communicative English world becomes larger and larger as EFL learners do not receive sufficient opportunities for cohesion input and output. Only with numbers of chances for input and output, the learners, even low-achievers, would conveniently connect to the real world outside classrooms. English writing is not easy to learn, however, building up a learner corpora is an alternative way to learn from mistakes or errors. L1 plays both positive and negative influences on L2 learning. Through sufficient drills and practices, it would be possible to turn negative outcomes into positive ones.

\section{Limitations and Suggestions}

The major limitation is the small size of the learner corpus. It only included two classes of EFL learners, and they were all from the same university. Diversity in learners would lend stronger support to the study findings. Future relevant studies could be conducted in a larger scale for broader generalizations.

\section{References}

Bax S (2003) The end of CLT: A context approach to language teaching. ELT Journal 57(3): 278-287.

Bolton K, Nelson G, Hung J (2003) A corpus-based study of connectors in student writing: Research from the International Corpus of English in Hong Kong (ICE-HK). International Journal of Corpus Linguistics 7(2): 165-182.

Cameron CA, Lee K, Webster S, Munro K, Hunt AK, Linton MJ (1995) Text cohesion in children's narrative writing. Applied Psycholinguistics 16(3): 257-269.

Chafe W (1985) Linguistic differences produced by differences between speaking and writing. In D Olson, $\mathrm{N}$ Torrance, A Hildyard (Eds.), Literacy, language, and learning: The nature and consequences of reading and writing (pp. 105-123). New York, NY: Cambridge University Press. 
Chen C W-Y (2006) The use of conjunctive adverbials in the academic papers of advanced Taiwanese EFL learners International Journal of Corpus Linguistics 11(2): 113-130.

Cox BE, Shanahan T, Sulzby E (1990) Good and poor elementary readers' use of cohesion in writing. Reading Research Quarterly 25(1): 47-65.

Halliday MAK, Hasan R (1976) Cohesion in English. London: Longman.

Hamed M (2014) Conjunctions in Argumentative Writing of Libyan Tertiary Students. English Language Teaching 7(3): 108-120.

Divsar H, Heydari R (2017) A Corpus-based Study of EFL Learners' Errors in IELTS Essay Writing. International Journal of Applied Linguistics and English Literature 6(3): 143-149.

Huang SC, Chang SF (1996) Self-Efficacy of English as a second language learner: An example of four learners. ERIC Number: ED396536. Retrieved from goo.gl/Mo1XVH

Hung MF (2003) A Study on the Use of Conjunctions in Compositions by Taiwanese Senior-high-school Students. Master Thesis, National Chengchi University, Taiwan.

Lo KC (2003) An Analysis of Senior High School Students' English Compositions in Terms of Conjunction. Master Thesis, National Chengchi University, Taiwan.

McClure E (1993) What Do You Include in a Narrative? A Comparison of the Written Narratives of Mexican and American Fourth and Ninth Graders. ERIC Number: ED396559. Retrieved from goo.gl/8C2isR.

Oxford RL (1990) Language learning strategies: What every teacher should know. Boston, Mass: Heinle \& Heinle Publishers.

Reid J (1992) A computer text analysis of four cohesion devices in english discourse by native and nonnative writers. Journal of Second Language Writing 1(2): 79-107.

Sumonsriworakun P, Pongpairoj N (2017) Systematicity of 11 thai learners' English interlanguage of dependent prepositions. Indonesian Journal of Applied Linguistics 6(2): 246-259.

Tanskanen S-K (2006) Collaborating Towards Coherence: Lexical Cohesion in English Discourse. PA, USA: John Benjamins Publishing Company.

Tarone E, Yule G (1989) Focus on the language learner. Oxford: Oxford University Press.

Wei DD (2004) Rethinking the English pedagogy at Hope College in Taiwan. Paper presented at the AARE, Melbourne, Australia.

Xu Y, Liu Y (2012) The Use of Adverbial Conjuncts of Chinese EFL Learners and Native Speakers-Corpus-based Study. Theory and Practice in Language Studies 2(11): 2316-2321. 